\title{
The structure of assessment and control activities of children before school age in the vector of modernity
}

\author{
I. V. Saraieva \\ Postgraduade student at the Department of Theory and Methods of Preschool Education \\ (South Ukrainian National Pedagogical University named after K. D. Ushynsky) \\ Corresonding author. E-mail: ladybug82@ukr.net
}

Paper received 28.07.21; Accepted for publication 16.08.21.

\section{https://doi.org/10.31174/SEND-PP2021-256IX100-04}

Annotation. The article positions the views of scientists on the structural components of assessment and control activities and the need for their development in preschool children in a specially created pedagogical environment. The essence of the concepts "evaluation", "evaluation actions", "evaluation judgments", "control", "control actions", "evaluation and control activities" is revealed. The pedagogical conditions of its implementation are determined, which will promote the effective formation of children's evaluation and control actions in various activities.

Keywords: assessment, control, evaluation actions, control actions, evaluation-control activity, children before school age, pedagogical conditions.

The relevance of the problem of involving children of older preschool age (5-6 years) in assessment and control activities in preschool education institutions of Ukraine is primarily related to the mental preparation of children for school, with the development of critical thinking in various types of educational activities in accordance with the Concept of the new Ukrainian school, which is actively implemented in the modern primary school of Ukraine. Any educational activity of a critical orientation requires children to have assessment and control (self-assessment and self-control), that is, conscious assessment and control actions, and is the structural core, the core of the assessment and control activities of children in the process of any organized classes in various sections of the program, in independent games, in relationships with other children and adults; and in the child's daily behavior.

It should be noted that the problem of forming in preschool children the actions of assessment (selfassessment) and control (self-control) was in the centre of attention of scientists in the 60-80s of the twentieth century. Unfortunately, from the 80 s of the twentieth century to the present independent state - Ukraine - scientific research on the organization of evaluation and control activities have not been the subject of research by scientists. There is a need to turn to the existing scientific fund of research on this problem in the second half of the twentieth century.

Theoretical issues of evaluation and control activities in the educational process of various educational institutions were studied by psychologists (B. Ananiev, E. Arkhipova, P. Blonsky, M. Boryshevsky, I. Bronnikov, L. Vygotsky, P. Halperin, N. Gnedova, L. Itelson etc.), teachers (Sh. Amonashvili, Y. Babansky, T. Doronova, N. Talyzina, etc.), scientists of the preschool branch of science $(\mathrm{N}$. Ankudinova, O. Anishchenko, E. Arkhipova, M. Goloshchokina, I Domashenko, T. Doronova, T. Komarova, L. Tkachenko, R. Shakurov, etc.). The works of scientists of that time covered mostly methodological issues of forming evaluative judgments in children of the process and result of their activities of other children (mutual evaluation), as well as the formation of self-control in preschool children in various activities.

A fundamental study on the structure of assessment and control activities and the formation of assessment and control actions in older preschool children in the conditions of bilingualism was conducted for the first time in Ukraine by Academician AM Bogush [4].

We characterize the structural components of evaluation and control activities, in particular such concepts as "evaluation", "evaluation actions", "self-evaluation"; "control", "control actions", "self-control", "evaluation and control actions", "evaluation and control activities".

In dictionary sources, the concept of "assessment" is defined as: "attitude to social phenomena, human activity, behavior, establishing their significance, compliance with certain norms and principles of morality (approval and condemnation, consent or criticism, etc.)" [12, p.353]; "Measuring individual differences associated with personality traits" [20, p. 317]. In the "Encyclopedia of Education" "assessment" is presented as a process, a specific component of control and as a result that completes it. The concept of "assessment of learning outcomes" is defined as establishing the degree of assimilation of educational knowledge by students, the level of their quality [7, p.630].

According to A. Bogush, "evaluation always presupposes the reflection of what is happening in the subject, arises in his consciousness due to thinking and only later is taken out, becomes a material norm; evaluation is associated with critical thinking, which acts in the ability to adequately assess the work of thought (both their own and others) and the results of activities" [5, p. 93]. The scientist associates evaluation with evaluative attitudes, which, in her words, "consist of a set of conscious mental acts of a person, ie a set of evaluations" [5, p. 93]. A. Bogush defined the criterion of evaluation activity, which is the "evaluation standard", which is directly related to the evaluation and on the basis of which evaluation and control operations are carried out. According to the scientist, in the process of educational activity, externally set evaluation standards are further manifested in the form of acquired knowledge, experience, skills and form the basis of internal reflex evaluation. The scientist is convinced that evaluation is impossible without a standard [5, p. 93]. The author notes that evaluation always involves the reflection of what is happening in the subject, arises in his mind through thinking and only later is taken out, becomes a material norm. According to A. Bogush, evaluation is 
associated criticality of the brain, with critical thinking, which is the ability to adequately assess the work of thought (both their own and others) and the results of activities [5, p. 93]. A. Bogush claims that assessments are used both for educational and upbringing purposes and notes that under the influence of pedagogical assessment, children form evaluative actions [5, p. 95]. A. Bogush considers a model, an example of a verbal characterization of the behavior or deed of a person (a hero of a work of art) in accordance with the established norms adopted in a given society - an evaluative standard of moral and ethical content, which is compiled on the basis of a moral code and etiquette accepted in society. According to A. Bogush, the concept of "evaluative action" is primarily a speech action, a specific statement that reflects in words a certain attitude of the child (person) to the subject of evaluation based on the analysis of the process (or result of activity); it is a speech action in which the motives that motivate the child to choose the appropriate assessment are revealed "[ 5 , p. 95]. The scientist claims that evaluation actions are aimed at evaluating the results of educational activities and are the basis for analyzing the process of activity, comparing the obtained result with the specified requirements. According to A. Bogush, evaluative actions are speech actions, in the process of which the motives that motivate the child to choose the appropriate assessment and the manifestation of a certain attitude of the child to the subject of assessment are revealed [5, p. 95].

Sh. Amonashvili agree with the opinion of A. Bogush who expresses the opinion that "evaluation" is "a process, activity (or action) of evaluation carried out by a person; "Score" - is the result of this process, this activity (or action), their conditional-formal reflection. Sh. Amonashvili believed that "all our approximate and in general any activity in general depends on the assessment" [2, p. 8]. According to Sh. Amonashvili, the basis of evaluation activity is a standard that must be initiated in advance in the educational and cognitive task as a goal and direction of activity. On the basis of the standard evaluation and control operations are carried out. Standards that have been formed and presented from the outside, are further defined in the form of knowledge, experience, skills and become the basis of internal reflex assessment. The scientist believed that the success of assessment and educational activities is determined by the presence of appropriate standards. Thus, evaluation is impossible without standards [5, p. 32]. The child's ability to operate by standards and exercise self-control and self-assessment leads to the completion of the teacher's assessment, said Amonashvili. The scientist considered the evaluation activity of the teacher and the collective content of the evaluation as the basis for the formation of the child's self-esteem [5, p. 41].

Note that we can not disagree with the scientific position of scientist N. Talizina, who considered the assessment is not a quantitative measurement of knowledge, but an arbitrary number that can correspond to certain characteristics of knowledge and skills formed at a certain level $[17$, p. 162].

Scientists (Sh. Amonashvili, Y. Zotov, T. Ilyina, O. Savchenko, A. Khutorskaya and others) distinguish five main functions of assessment: motivational (stimulating) stimulates the educational activities of the child and its continuation; diagnostic - indicates the causes of certain educational outcomes of the child; educational - forms self-awareness and adequate self-esteem of the child's educational activities; information - informs about the degree of success of the child in achieving educational standards, mastery of knowledge, skills and methods of activity, development of abilities; indicative - directs the child to eliminate certain gaps in knowledge.

Scientists have characterized the types and functions of assessment and evaluation. The most influential type in educational activities with children is pedagogical assessment.

According to A. Bogush, evaluation standards are expressed in the evaluations of teachers, in pedagogical evaluations [5, p. 94]. The scientist interprets the concept of "pedagogical assessment" as "adequate positive or negative judgment of the teacher about the process (or result) of the child's activities and deeds." Under the influence of the teacher's assessment, the first children's evaluation judgments are born and formed [5, p. 94]. Scientists (A. Bogush, O. Usova, E. Florina) have formed the conditions under which pedagogical assessment will have a positive impact on the assessment of children, such as: a) the teacher constantly focuses children's attention on various aspects of children's behavior and in various activities; b) forms in the minds of children general criteria for assessing the rules of conduct and relationships; c) draws children's attention to independent activity; d) emphasizes in the content of his assessment of the child's progress, his moral growth; e) directs to the result of the activity, and not to the child [5, p. 95].

B. Ananiev singled out two functions of the influence of assessment on the child in the process of education and training: 1) indicative, during which the child by means of pedagogical assessment is aware of the result of their actions; 2) stimulating, which encourages action through the child's experiences of success or failure. The combination of these functions of pedagogical assessment forms the child's self-awareness and self-esteem [3, p. 120]. The scientist believed that pedagogical assessment changes in the team, under the influence of pedagogical assessment; in the family - changing the relationship between the child and the family in a positive (nurturing this relationship) and negative (makes adjustments between the preschool and the family) influence and on the part of the child. The generalization of all this is the mutual assessment of the teacher, family, team and the child, which is the reverse side of an important result of pedagogical assessment - the child's self-esteem [3, p. 131].

B. Ananiev, considering assessment as a dynamic system, identified three levels of its development: 1) partial assessments (individual judgments of the teacher about the quality of the child's personality and its achievements during the survey); 2) fixed grades (scores that indicate the grade); 3) integrated assessments (pedagogical characteristics). The scientist divided partial assessments into three large groups: a) lack of assessment, indirect assessment, indefinite assessment; b) negative assessments formed by remarks, objections, condemnations with the addition of sarcasm, reproaches, threats, notations; c) positive assessments formed by consent, encouragement, approval. According to the scientist, partial assessment in the mind of the child serves as the foundation of objective self-assessment and forms the level of its assessment 
needs (assessment demands), which precedes the current account of success in its fixed form as a necessary component [3, p. 144].

Thus, assessment means the process of comparing and comparing the knowledge, skills and abilities of children with the given pedagogical requirements, which is associated with a critical attitude of the child to the process and result of different activities.

According to G. Lublinska, evaluation activity is a special form of human activity, which is constantly evolving and enables him to understand the environment with the greatest accuracy and objectivity and to establish a reliable and useful connection with it. It helps to "understand what the eyes see and hear the ears, to understand the valuable, the good, the promising, to consolidate and reject or condemn the bad, the negative" [10, p. 58].

Touching upon the problem of the development of the personality of a preschool child, G. Uruntayeva convincingly notes that it is the adult who stimulates the formation of the child's evaluation activities by identifying his own attitude to the environment and evaluation approach; the direction of the child's activities through the accumulation of experience of individual activities, tasks, means of solving and evaluating their performance, as well as through systematization, generalization, awareness and verbalization of this experience; presentation of samples of activity, thus presenting to the child criteria of correctness of its performance; organization of joint activities with peers, which helps the child to see in others a person, take into account their wishes, take into account their interests, in addition to transfer to communication with peers patterns of activities and behavior of adults [19, p. 257].

Under the evaluative activity of preschool children we understand the expression of a critical attitude of the child to the process and result of various activities.

Among the many characteristics of personality, selfesteem is the core of arbitrary self-regulation, which determines the direction and level of human activity, his attitude to others, people, himself. Self-esteem is a psychologically complex phenomenon. It is a component between many connections and relationships with all mental formations of the individual and acts as an important determinant of all forms, activities and communication. The formation of self-esteem begins at an early age and continues to develop and improve throughout later life.

The educational program "Confident Start" for older preschool children characterizes the degree of psychological maturity of the preschooler by the formation of selfawareness, which includes one of many factors - adequate self-esteem. Easy adaptation of the child to the new social status of the student is the result of the formation of adequate self-esteem in preschool children, which is a topical issue today.

In psychological and pedagogical research on the development of self-esteem in preschool children, attention has been paid to many scientists: the development of selfesteem, the structure of function are revealed in the works of L. Bozhovich, I. Kon, M. Lisina, E. Erickson, K. Rogers, etc .; regularities of self-esteem formation in childhood were considered by L. Bozhovych, V. Gorbacheva, M. Lisina, V. Mukhina, etc.; Manifestations and features of self-esteem in the behavior of a preschool child were studied by B. Ananiev, I. Bronnikov, M. Lisina, R. Shakurov, and others.

In many psychological and pedagogical terminological sources there is a consensus on the definition of "selfesteem" - is the assessment of the individual himself, their capabilities, qualities and place among other people [20, 13, 12, 8]. In the Encyclopedia of Education, the concept of "self-esteem" is presented as a "psychological personality formation, which gives a person the opportunity to assess their physical and spiritual condition, their capabilities, orientation, activity, social significance, their relationships with the outside world and other people. Selfesteem is a prerequisite for the realization of two important states of self-directed behavior: self-control and self-improvement" [7, p. 799].

S. Honcharenko characterizes the concept of "selfesteem" as a human judgment about the degree of presence in it of certain qualities, properties in relation to a certain standard, sample. The scientist believes that selfesteem is not only a manifestation of self-esteem, but also the result of mental operations - analysis, comparison, synthesis [18, p. 296].

The level of development of self-esteem, according to A. Bogush, affects the formation of self-control, ie selfesteem precedes the formation of self-control. The scientist defines self-esteem as "a conscious attitude of an individual to his actions, deeds, behavior, environment and to himself, which is based on comparing and comparing the process and results of his activities with a given pattern and requirements of society, other people or the individual. Self-esteem cannot exist outside of thinking and speaking "[ 1, p. 201]. The difference between self-control and self-esteem, the scientist sees in the regulation of their activities in accordance with the requirements of others or the individual himself. Self-assessment is the basis of selfcontrol, because self-control begins and ends with selfassessment [1, p. 201]. There is a close relationship between self-esteem and self-control, as noted by A. Bogush, but they are preceded by mutual evaluation and mutual control, which are used by the individual in the process of combining, i.e. mastered evaluation criteria personality transfers to their own activities [1, p. 206]. A. Bogush convincingly proves that the communication of children with adults and the authority of the educator plays a significant role in the formation of self-esteem, because it is under the influence of the teacher it becomes objective and adequate [1, p. 203]. The scientist's research proves that the pedagogical assessment and control used in the process of communication determine the formation of similar assessment and control actions in children. According to A. Bogush: "evaluation and control actions are a prerequisite for such components of educational activities as self-evaluation and self-control", which include: the ability to evaluate and control the activities of peers, ie mutual evaluation and mutual control; the ability to evaluate and control their own activities, ie self-esteem and self-control [1, p. 195]. The scientist argues that in the process of educational activities, evaluation and control actions perform a dual function: first, as a condition and means of learning, the formation of appropriate speech skills; secondly, as an important condition for the application of acquired knowledge, acquired skills and abilities. 
According to A. Bogush, the evaluation and control actions that preschool children should have include: mutual evaluation and mutual control, self-evaluation and selfcontrol [1, p. 206].

Examining the mental development of a preschool child, D. Elkonin notes that self-esteem is fully formed in a child before entering primary school and has the following components: the presence of skills related to practical activities and moral qualities manifested in submission or disobedience to the rules of behavior that exist in a particular team. So, a preschool child goes from "myself", to separating himself from an adult to self-knowledge, to discovering his inner world, which is strongly connected and coordinated with external activities [21, p. 141].

M. Lisina considers self-esteem more in a narrow sense because it separates it from the elements of imagination, the child's knowledge of himself. The scientist distinguishes the following types of self-esteem: general (related to the holistic attitude of the child to himself as a favorite of others, whether it is important for them, or vice versa, as an insignificant being); specific ( reveals the child's attitude to the success of his separate, private action); absolute (reveals the child's attitude to himself outside of his relationship with other people, as an experience of whether he is loved at all or not); relative (reveals the child's attitude to himself in comparing himself with other people)[ 9, p. 136].

Thus, under the self-esteem of preschool children we understand the evaluative judgments of the child about personal qualities, about the process and result of their activities.

Thus, the analysis of the scientific literature showed that in psychological and pedagogical science quite thoroughly positioned theoretical positions on the nature, types and characteristics of the concepts of "assessment", " estimate " and their types and functions. Let us now turn to the concept of "control".

In psychological and pedagogical terminological sources, the concept of "control" is defined differently: "a type of activity that consists in checking something, someone" [14, p. 80]; "One of the relatively complete mechanisms of regulation of cognitive processes" [20, p. 214]; "The final component of mastering a certain content block and a kind of link in the system of educational activities of the individual" [7, p. 417]. The main tasks of control are to identify the level of accuracy, volume, depth and effectiveness of knowledge acquired by children, obtaining information about the nature of cognitive activity, the level of independence and activity of children in the educational process, establishing the effectiveness of methods, forms and methods of teaching. The process of control and evaluation of children's educational activities should take into account the principles of systematicity, objectivity, differentiation and consideration of individual characteristics of children, publicity, unity of requirements, friendliness [7, p. 417].

Under control actions A. Bogush understands "conscious regulation of the child's speech activity to prevent, identify and correct speech errors, as well as ensuring compliance of educational results with the submitted (or compiled independently) plan, requirements, sample, pronunciation standards" [1, p. 206].

M. Yarmachenko distinguishes the narrow and broad meaning of "control": first - it is "supervision, observation, verification of student performance"; secondly, "control helps to identify gaps in knowledge and skills of students, repetition and systematization of material, establishing the level of readiness to learn new material, developing the ability to work responsibly and focused, use techniques of self-examination and self-control, stimulating students' responsibility and competitiveness" [7, p. 417].

An important component of educational activities that should be formed in every child, as noted by E. Rapatsevich, is control and self-esteem, which are essential in the educational process. The scientist notes that the lack of control leads to the inability to assess what is in the future a prerequisite for learning difficulties [11, p. 330]. In order to form the child's control and selfesteem, E. Rapatsevich suggests bringing one simple thing to the child's consciousness: "only by telling the educational material to yourself, peers, and parents can you make sure that you have learned it or not. That is, to demonstrate the control function of repetition." The next necessary condition, the scientist sees the need to accustom the child to constant comparison, comparison of their work with any sample, both during the task and after its completion. After all, it is the independent verification of these actions and the comparison of the result with the answer, for all their differences perform the same function - control [11, p. 332].

N. Talyzina notes that control is an integral part of learning. An important condition for the effective acquisition of knowledge by children, the scientist considered the systematic control over the acquisition of knowledge and the timely introduction of appropriate adjustments in this process [17, p. 149]. N. Talyzina notes that attention is self-control, which is carried in your minde, abbreviated, automated. The scientist is convinced that attention is the action of control, at the same time, in her opinion, not every action of control is attention, only the action that the child keeps in mind, reduced and automated, ie attention is the final stage of mastering control [17, p. 243].

O. Rudnytska considers control in musical activity not only as a component of the functional structure of musical activity, which is carried out in accordance with its main and intermediate goals, conditions and forms of performance, tasks, but also an independent activity with a specific purpose - " establishing the correspondence of what is being checked to what was supposed to be obtained according to a certain standard" $[15, \mathrm{p} .161]$. The scientist notes the complexity of the control structure and reveals the components of control, which are its specific functions: detection of what is controlled (knowledge, understanding, skills, actions, motives, etc.), measurement of what is detected and its evaluation [15, p. 161]. The main factors on which the result of control depends, O. Rudnytska considers objective (actually the semantic side of the child's activity) and subjective (the position of the teacher, due to his pedagogical skills to express knowledge, qualities of delicacy, tact, humane attitude to the child, chosen tactics and strategy of professional activity) [15, p. 164] The scientist outlined various forms of control, which are used depending on the tasks, stages of training and goals of accounting for work, such as: current and boundary; oral (conversation, survey) and written (control tasks); 
direct (in interaction with the child) and indirect (based on the results of her work); individual (detailed, in the process of individual lessons) and frontal (with the help of separate questions to all children who answer in the process of group lessons); non-standardized (carried out by the teacher) and standardized (carried out using the same type of questionnaires for all children using templates and technical means of processing results; covert and explicit (with warning of children to check); planned and unexpected; control by the educator and mutual control by children. O. Rudnytska also considers such means of control as: observation, questions and tasks (questionnaires, tests, tasks, assignments) [15, p. 165].

Thus, under the control actions of preschool children we understand the ability of the child to juxtapose and compare their own actions, process and result of activities with externally set requirements or pattern.

Examining the problem of educating self-control in the behavior of primary school children, M. Boryshevsky noted that an indispensable condition for the moral development of the child, an essential criterion of his upbringing is the ability to self-control their own actions and deeds. According to the scientist, the formation of selfcontrol in children has a close relationship with the practical solution of moral norms and rules of conduct in internal regulators [6, p. 140]. The leading condition for the effective formation of self-control in children, M. Boryshevsky considered providing each child with a position in the team of peers, which gives him the opportunity to act as an object and as a subject of activity and behavior. The scientist puts forward the following requirements to teachers, which will contribute to the successful formation of children's assessment and control functions and deeper mastery of norms of behavior: involving children in the simplest requirements and monitoring their implementation by peers; pay special attention to the development of a system of mutual control and education on this basis in children of mutual responsibility; the need for a comprehensive approach to the formation of self-control of the behavior of pupils, who must simultaneously act on various aspects of the child's mental activity, its intellectual, emotional and volitional spheres [6, p. 141].

Thus, the self-control of preschool children means the child's ability to independently adjust, juxtapose, compare the process and result of their activities in accordance with the requirements proposed or developed (by the child) plan, timely correction and elimination of deficiencies, both in the process and in a result of the activity.

In particular, E. Rapatsevich presents the structure, types and functions of the evaluation and control act. Consider each of them.

The structure of the evaluation and control act:

- performance by the educator and pupils consciously, developed as a sequence of actions, external and internal evaluation and control activities;

- any evaluation and control activity consists of separate acts of control and evaluation in which the object of control and evaluation and the standard with which the object is compared are present;

- the object of control and evaluation may be the fact that the child performs any action, deed, task of the educator, the nature and features of the child's performance of this task, action, the level of his knowledge, skills, devel- opment of any quality, personality traits;

- the standard of activity is the entity that exercises control;

- control is a process of comparison, comparison, establishment of common or different in the object and the standard;

- the subject chooses any criterion by which to assess the object of control, formulates the result of the assessment in the form or detailed assessment [11, p. 333].

Depending on the subject who carries out the assessment and control act E. Rapatsevich divides them into external, carried out by the educator and internal, carried out by the child. External evaluation and control acts, depending on the purpose of the educator are divided into the following: ascertaining, with which the teacher certifies the fact that children perform any tasks, the presence of anything; examiners, with the help of which the teacher finds out the quality of children's mastery of knowledge, skills and abilities; diagnostic, with which the teacher certifies the level of development of children's mental processes (attention, memory, thinking, imagination), personality qualities (interests, motivations, etc.), educational skills [11, p. 339].

Functions of external evaluation and control acts: 1) orientation of the educator in the process of educational activity of each child, in the process of development of his personality allows to purposefully plan his educational activity and timely adjust the process of its implementation; 2) the orientation of the educator of children on their achievements in educational work and shortcomings excites them to intensify their work, to eliminate these shortcomings; 3 ) the formation of the child's correct idea of the required level of mastery of educational material, the development of each child's adequate self-assessment of their educational opportunities in any activity should promote conscious self-determination, education and development of established interests and inclinations; 4) teaching children the techniques of mutual and self-control, mutual and self-esteem in any activity; 5) attention can be considered as mental control (according to P. Halperin) [11, p. 340].

Thus, the formation of evaluation and control actions in preschool children depends on: the type of activity in which evaluation and control actions are offered to the child; the nature of pedagogical assessment and control used by the educator in speech development classes; the number of errors in the story and the nature of speech; assessment situation (actions aimed at the speech of another or on their own); the degree of language acquisition by children; mutual and self-control [1, p. 288].

Thus, we can generalize and position our vision of the concept of evaluation and control activities of preschool children - stimulated activity of children to critical attitude and evaluation of the process and result of various activities, which include conscious actions of evaluation, control, self-evaluation, self-control, mutual evaluation, mutual control.

Starting an experiment of research on the formation of evaluation and control actions in preschool children in different activities, the pedagogical conditions were determined, the implementation of which will ensure the successful formation of evaluation and control actions in children in different activities. Among them: the integra- 
tion of different activities in the formation of assessment and control activities in preschool children; stimulating children's critical attitude to the process and result of vari- ous activities; the presence of emotionally positive stimuli to the evaluation and control activities of children before school age.

\section{ЛИТЕРАТУРА}

1. Алла Богуш. Мовленнєвий розвиток дітей від народження до 7 років. Монографія. К.: Видавничий дім «Слово», 2004. $376 \mathrm{c}$.

2. Амонашвили Ш. А. Обучение, оценка, отметка. М.: Знание, 1980.96 с.

3. Ананьев Б.Г. Избранные психологические труды: В 2-х т. Т. II / Под ред. А.А. Бодалева и др. М.: Педагогика, 1980. $288 \mathrm{c}$.

4. Богуш А. М. Формирование оценочно-контрольных действий у дошкольников в процессе обучения родному русскому языку: автореф. дис. на соискание ученой степени д-ра пед наук: 13.00.02 / АПН СССР, НИИ преподавания назв.).

5. Богуш А., Гавриш Н., Котик Т. Методика організації художньо-мовленнєвої діяльності дітей у дошкільних навчальних закладах. Підручник для студентів вищих навчальних закладів факультетів дошкільної освіти. К.: Вищий Дім «Слово», 2006. 304 с.

6. Боришевський М. Й. Виховання самоконтролю в поведінці учнів початкових класів: Посібник для вчителів. К.: Рад. Школа, 1980. 143 с.

7. Енциклопедія освіти / Акад. пед.наук України; головний ред. В. Г. Кремень. К.: Юрінком Інтер, 2008.1040 с.

8. Коджаспирова Г. М., Коджаспиров А, Ю. Словарь по педагогике. Москва : ИКЦ «МарТ»; Ростов н/Д: Издательский центр «МарТ», 2005. 448 с.

9. Лисина М. И. Общение, личность и психика ребенка. / Под редакцией Рузской А. Т. М. : Издательство «Институт практической психологии», Воронеж: НПО «МОДЕК», 1997. 384 c.

10. Люблинская А. А. Учителю о психологии младшего рус. яз. в нац. шк. М., 1985. 52 с. Библиогр.: с. 45-52 (109

школьника. Москва: Просвещение, 1977. 224 с.

11. Новейший психолого-педагический словарь / сост. Е. С. Рапасевич; под. оющ.ред. А. П. Астахова. Минск: Совершенная школа, $2010.928 \mathrm{c}$.

12. Педагогічний словник (за ред. Дійсного члена АПН України Ярмаченка М. Д. К.: ПЕДАГОГІЧНА ДУМКА, $2001.516 \mathrm{c}$.

13. Психология. Словарь / Под общ. ред. А. В. Петровского, М. Г. Ярошевского. 2-е узд., испр. и доп. М.: Политиздат, $1990.494 \mathrm{c}$.

14. Психологічний словник / За ред. В. І. Войтка К.: Головне видавництво видавничого об'єднання «Вища школа», $1982.217 \mathrm{c}$.

15. Рудницька О. П. Педагогіка: загальна та мистецька. Навч. Посібник. К.:.., 2002. 270 c.

16. Словарь по образованию и педагогике / В. М. Полонский. М.:Высш.шк., 2004. 512 с.

17. Талызина Н. Ф. Педагогическая психология: Учеб. для студ. сред. пед. учеб. Заведений. - 3-е изд., стереотип. М.: Издательский центр «Академия», 1999. 288 с.

18. Український педагогічний словник. Семен Гончаренко. К.: Либідь, 1997. 374 с.

19. Урунтаева Г. А. Детская психология: ученик для студ. учреждений высш. Проф.. образования / Г. А. Урунтаева. М.: Издательский центр «Академия», 2013. 336 с.

20. Шапар В. Б. Сучасний тлумачний психологічний словник. Х.: Прапор, 2005. 640 с.

21. Эльконин Д. Б. Психическое развитие в детских возрастах: Избранные психологические труды / Под ред. Д. И. Фельдштейна; Вступительная статья Д. И. Фельдштейна. 3-е изд. М.: Московский психолого-социальный институт, Воронеж: НПО «МОДЭК», 2001. 416 с.

\section{REFERENCES}

1. Bohush Alla. Speech development of children from birth to 7 years. Monograph. K.: Vydavnychyi dim «Slovo», 2004. 376 p.

2. Amonashvyly, Sh. A. Training, assessment, mark. M.: Znanye, $1980.96 \mathrm{p}$.

3. Ananev, B.G. Selected psychological works: In 2 volumes. T. II / Ed. A.A. Bodaleva et al. M.: Pedagogika, 1980. 288 p.

4. Bohush, A.M. Formation of evaluative and control actions in preschoolers in the process of teaching their native Russian language: author. dis. for the degree of Doctor of Pedagogy: 13.00.02 / APN USSR, Research Institute of Teaching Rus. lang. in nat. sch. M., 1985. $52 \mathrm{p}$.

5. Bohush, A., Havrysh, N., Kotyk, T. Methods of organizing artistic and speech activities of children in preschool educational institutions. Textbook for students of higher educational institutions of preschool education faculties. K.: Vyshchyi Dim «Slovo», 2006. 304 p.

6. Boryshevskyi, M. Y. Education of self-control in the behavior of primary school students: A guide for teachers. K.: Rad. Shkola, 1980. 143 p.

7. Kremen, V. H. Encyclopedia of Education / Acad. Pedagogical Sciences of Ukraine. K.: Yurinkom Inter, 2008.1040 p.

8. Kodzhaspirova, G. M., Kodzhaspirov, A. Yu. Dictionary of Pedagogy. Moskva : IKTs «MarT»; Rostov n/D: Izdatelskiy tsentr «MarT», 2005. $448 \mathrm{p}$.

9. Lisina, M. I. Communication, personality and psyche of a child. / Edited by Ruzskaya A. T. M. : Izdatelstvo «Institut prakticheskoy psihologii», Voronezh: NPO «MODEK», 1997. 384 p.
10. Lyublinskaya, A. A. Teacher about the psychology of a younger student. Moskva: Prosveschenie, 1977. 224 p.

11. Rapasevich, E. S. The newest psychological and pedagogical dictionary. Minsk: Sovershennaya shkola, 2010. 928 p.

12. Yarmachenka, M. D. The latest psychological and pedagogical dictionary. K.: PEDAHOHIChNA DUMKA, 2001. 516 p.

13. Petrovskogo, A. V., Yaroshevskogo, M. G. Psychology. Dictionary. M.: Politizdat, 1990.494 p.

14. Voitka, V. I. Psychological Dictionary. K.: Holovne vydavnytstvo vydavnychoho obiednannia «Vyshcha shkola», 1982. $217 \mathrm{p}$.

15. Rudnytska, O. P. Pedagogy: general and artistic. Teaching. Manual. K.:.., 2002. 270 p.

16. Polonsky, V. M. Dictionary of education and pedagogy. M.:Vyissh.shk., 2004. 512 p.

17. Talyizina, N. F. Educational psychology: Textbook. for stud. wednesday ped. study. Establishments. - 3rd ed., Stereotype. M.: Izdatelskiy tsentr «Akademiya», 1999. 288 p.

18. Honcharenko, Semen. Ukrainian pedagogical dictionary. K.: Lybid, 1997. $374 \mathrm{p}$.

19. Uruntaeva, G. A. Child psychology: student for students. institutions of higher. M.: Izdatelskiy tsentr «Akademiya», 2013. 336 p.

20. Shapar, V. B. Modern explanatory psychological dictionary. Kh.: Prapor, 2005. 640 p.

21. Elkonin, D. B. Mental development in childhood: Selected psychological works. M.: Moskovskiy psihologo-sotsialnyiy institut, Voronezh: NPO «MODEK», 2001. 416 p. 